\title{
Effects of buffer additions on fermentation of dormant range grasses
}

\author{
P.A. MOMONT, R.J. PRUITT, R.H. PRITCHARD, AND P.S. JOHNSON
}

\begin{abstract}
Authors are former graduate assistant, associate professor, professor, and associate professor, Department of Animal and Range Sciences, South Dakota State University, Brookings 57007-0392. P.A. Momont is currently assistant professor, Department of Animal Science, Southwest Research and Extension Center, Caldwell, Ida. 83605.
\end{abstract}

\begin{abstract}
Replicated two-stage in vitro studies were conducted to determine the effects of single amino acid or branched-chain volatile fatty acid buffer additions on in vitro dry matter disappearance, neutral detergent fiber disappearance, and fermentation kinetics of dormant range grasses. Substrates consisted of separate samples of $\mathbf{2}$ cool season mid-grasses, western wheatgrass (Agropyron smithii Rydb.) and Japanese brome (Bromus japonicus Thunb.), and a mixture of warm season shortgrasses, buffalograss (Bunchloe dactyloids [Nutt.] Engelm.), and blue grama (Bouteloua gracilis [H.B.K.] Lag. ex Steud.), hand clipped from standing forage in mid-March. Isonitrogenous treatments included buffer containing urea with or without amino acids, branched-chain volatile fatty acids, sodium sulfate, or starch. Urea increased $(P<0.05)$ in vitro dry matter disappearance and in vitro neutral detergent fiber disappearance of the cool season grasses over $\mathbf{N}$ free buffer. Methionine addition increased $(P<0.05)$ in vitro neutral detergent fiber disappearance and rate of fermentation of both cool season grasses and in vitro dry matter disappearance of Japanese brome over urea alone. Sodium sulfate increased $(P<0.05)$ in vitro neutral detergent fiber disappearance of Japanese brome compared to urea alone. None of the branched-chain volatile fatty acids tested increased dry matter disappearance, neutral detergent fiber disappearance, or rate of fermentation of the dormant range grasses. Addition of urea or amino acids did not increase in vitro dry matter disappearance or in vitro neutral detergent fiber disappearance of the shortgrass mixture. In vitro screening of amino acid and branchedchain volatile fatty acid buffer additions to dormant range grasses showed that methionine supplementation with urea offers the greatest potential, among the supplements evaluated, for improving digestibility and rate of fermentation of cool season grasses. None of the buffer supplements improved fermentation of the warm season grasses.
\end{abstract}

Key Words: gas production, fiber disappearance, urea, sulfur, starch

Urea based protein supplements typically limit performance of ruminants consuming mature low protein forages in comparison to animals fed oilseed meal supplements (Williams et al. 1969;

Published with the approval of the director of the South Dakota Agr.. Exp. Sta. as Publ. No. 2504 of the Joumal Series.

Manuscript Accepted 7 Nov. 1994
Rush and Totusek 1976; Clanton 1978). Identification of constituents contained in natural protein supplements that benefit ruminal fermentation and ultimately enhance animal performance could lead to more effective nitrogen supplementation. Inclusion of amino acids (Maeng et al. 1976; Clark and Peterson 1985), branched-chain volatile fatty acids (Soofi et al. 1982; Mir et al. 1986), or minerals (Spears et al. 1976; Slyter et al. 1988) with urea have been shown to increase substrate digestibility and (or) rate of fermentation in vitro. The response to a given addition was not consistent for all fiber sources in those studies. The objective of this study was to screen amino acids and branchedchain volatile fatty acids as potential urea-grain supplement additions which would serve to increase forage utilization by cattle consuming dormant range grasses.

\section{Materials and Methods}

Three trials (replicated twice) utilizing two-stage in vitro fermentations (Tilleys and Terry 1963, as modified by Martin and Barnes 1980) were conducted for each of 2 cool season midgrasses, western wheatgrass (Agropyron smithii Rydb.) and Japanese brome (Bromus japonicus Thunb.), and a mixture of warm season shortgrasses, buffalograss (Buchloe dactyloids [Nutt.] Engclm.) and blue grama (Bouteloua gracilis [H.B.K.] Lag. ex Steud.). In mid-March, grass samples were hand clipped from dormant standing vegetation pastures located at the South Dakota State University Range and Livestock Research Station near Cottonwood, S.D. Grass was clipped approximately 1 to 3 $\mathrm{cm}$ above ground level. oven dried at $60^{\circ} \mathrm{C}$, ground through a Wiley mill (1 mm screen), and stored until used in the in vitro fermentations. Inoculum was obtained from ruminally fistulated cows provided ad libitum access to a mature prairie hay composed of $63 \%$ western wheatgrass, $35 \%$ Japanese brome, and $2 \%$ unidentified forage (sd $=10,11$, and $3 \%$ respectively) as determined by sorting 15 random subsamples. Analytical composition of the grass samples used as substrate and the prairie hay fed to fistulated cows are listed in Table 1.

Each of the 3 trials (western wheatgrass, Japanese brome, and shortgrasses) consisted of 2 individual 48 hour incubations (run). Nested within trial were isonitrogenous $(50 \mathrm{mg}$ supplemental $\mathrm{N} /$ deciliter buffer) treatments (Table 2) consisting of the following buffer additions: 1) urea, 2) to 6) urea and amino acid (argi- 
Table 1. Chemical composition of dormant range grasses and prairie grass hay"

\begin{tabular}{lcccc}
\hline \hline Item & $\begin{array}{c}\text { Western } \\
\text { wheatgrass }\end{array}$ & $\begin{array}{c}\text { Japanese } \\
\text { brome }\end{array}$ & $\begin{array}{c}\text { Shortgrass } \\
\text { mixture }\end{array}$ & $\begin{array}{c}\text { Grass } \\
\text { hay }\end{array}$ \\
\hline Dry matter, \% & 96.4 & 93.5 & 93.5 & 91.5 \\
Crude protein, \% & 2.8 & 3.0 & 4.1 & 5.9 \\
Ash $\%$ & 8.7 & 6.8 & 15.2 & 10.2 \\
Calicum, \% & .33 & .24 & .47 & .40 \\
Phosphorus, $\%$ & .05 & .04 & .06 & .11 \\
Sulfur, \% & .07 & .05 & .07 & .10 \\
Neutral detergent fiber, \% & 69.9 & 68.7 & 65.1 & 63.9 \\
Acid detergent fiber, \% & 43.6 & 50.6 & 35.9 & 33.7 \\
Lignin, \% & 2.7 & 2.0 & 3.2 & 2.4 \\
Acid insoluble silica, \% & 7.02 & 5.44 & 12.06 & 5.7 \\
\hline
\end{tabular}

Dry matter basis.

nine, histidine, isoleucine, leucine, or methionine), 7) to 9) urea and branched-chain volatile fatty acid (isobutyric, isovaleric, or 2-methyl butyric), 10) urea and sodium sulfate (isosulfer to methionine, $28.56 \mathrm{mg}$ sulfur/deciliter buffer), and 11) urea and corn starch (starch equal weight to methionine). Selection of amino acids and branched-chain volatile fatty acids was based on results from previous trials (Maeng et al. 1976; Clark and Peterson 1985) which indicated that these buffer additions may limit in vitro fermentation. Amino acid and branched-chain volatile fatty acid additions were isomolar $(.88 \mathrm{mmol} / \mathrm{deciliter}$ buffer), amino acids provided approximately $25 \%$ of supplemental N/tube. Arginine and histidine could not be simultaneously isomolar and isonitrogenous, and therefore $\mathrm{N}$ levels for these treatments were higher.

Triplicate samples of western wheatgrass, Japanese brome, and shortgrasses (both with and without urea included in the buffer) and blank tubes containing ruminal fluid and $\mathrm{N}$ free buffer accompanied all 6 runs for the 3 trials. Ruminal fluid was collected at approximately 1000 each day, transported to the laboratory in a thermos at $39^{\circ} \mathrm{C}$, and strained through 6 layers of cheese cloth. For each treatment, triplicate samples $(.5 \mathrm{~g})$ of grass were placed in $50-\mathrm{ml}$ polypropylene centrifuge tubes. Following addition of the buffer with supplements $(25 \mathrm{ml} / \mathrm{tube})$ and rumen fluid ( $5 \mathrm{ml} /$ tube), tubes were flushed with $\mathrm{CO}_{2}$ capped with a rubber stopper, and incubated at $39^{\circ} \mathrm{C}$. Polyethylene tubing passed through the stoppers allowed gas produced during fermentation to be vented from the in vitro tube into a 125 -ml Erlenmeyer flask where water was displaced by gas pressure through a second tube

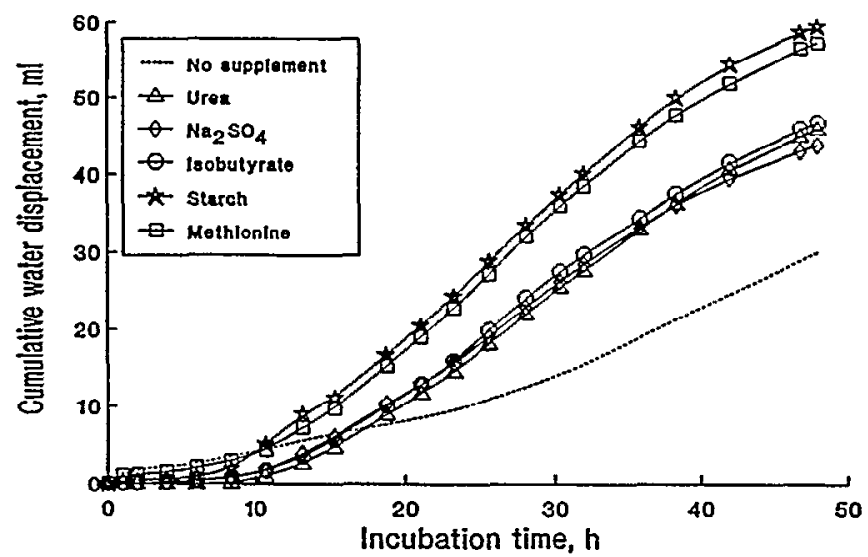

Fig. 1. Cumulative water displacement during 48 hour in vitro fermenttion of WWG with grass alone (no additions), urea alone, and urea plus $\mathrm{Na}_{2} \mathrm{SO}_{4}$, isobutyrate, starch, or methionine addition to the buffer solution.

into a $10-\mathrm{ml}$ graduated cylinder. Cumulative water displacement was recorded at 2 to 4 hour intervals over the 48 hour first stage fermentation period. Neutral detergent fiber analysis (Goering and Van Soest 1970) was conducted on grass samples and residues from the pepsin digestion to determine fiber disappearances.

Two separate analyses were conducted for this study. For the first analysis, effects of urea buffer addition on dry matter and neutral detergent fiber disappearances of the range grasses were analyzed as a two-way classification by least squares procedure using General Linear Models (GLM) of the Statistical Analysis System (SAS 1985). Supplement (Buffer alone or buffer with urea), range grasses, and their interaction were included in the model. Separation of the 6 subclass least squares means was accomplished by least significant difference. Gas production curves for incubations without added urea were linear and not included in analyses for determination of rate kinetics. Cumulative gas production curves for incubations with added urea were sigmoidal (Fig. 1). Nonlinear iterative least squares regression procedures (SAS 1981) were used to generate estimated rate kinetics (lag time, hour; rate of gas production, $\mathrm{ml}$ of $\mathrm{H}_{2} \mathrm{O}$ displaced/hour; and time of maximum gas production, hour; Fig. 2) as explained by Dybing et al. (1988). In a second set of analy-

Table 2. Buffer supplements for in vitro fermentation of dormant range grasses.

\begin{tabular}{|c|c|c|c|c|c|c|c|c|c|c|c|}
\hline \multirow[b]{2}{*}{$\begin{array}{l}\text { Buffer } \\
\text { supplement }\end{array}$} & \multicolumn{10}{|c|}{ Treatment } & \multirow[b]{2}{*}{11} \\
\hline & 1 & 2 & 3 & 4 & 5 & 6 & 7 & 8 & 9 & 10 & \\
\hline$\overline{\text { Urea }}$ & 106.4 & 106.4 & 100.0 & 100.0 & 100.0 & 100.0 & 100.0 & 106.4 & 106.4 & 106.4 & 106.4 \\
\hline L-histidine & & & 138.4 & - & - & - & - & - & - & - & - \\
\hline L-isoleucine & & & & 117.2 & - & - & - & - & - & - & - \\
\hline L-leucine & & & & & 117.2 & - & - & - & - & - & - \\
\hline Isovaleric & & & & & & & & 91.2 & - & - & - \\
\hline 2-methyl-butyric & & & & & & & & & 91.2 & - & - \\
\hline $\mathrm{Na}_{2} \mathrm{SO}_{4}$ & & & & & & & & & & 126.8 & - \\
\hline Starch & & & & & & & & & & & 133.2 \\
\hline
\end{tabular}


Table 3. Effects of urea addition on in vitro dry matter and neutral detergent fiber disappearance of dormant range grasses

\begin{tabular}{|c|c|c|c|c|}
\hline Item & $\begin{array}{c}\text { Western } \\
\text { wheatgrass }\end{array}$ & $\begin{array}{c}\text { Japanese } \\
\text { brome }\end{array}$ & $\begin{array}{c}\text { Shortgrass } \\
\text { mixture }\end{array}$ & SEM \\
\hline \multicolumn{5}{|c|}{$\begin{array}{l}\text { Dry matter } \\
\text { disappearance, } T_{0}^{1}\end{array}$} \\
\hline Without urea & $39.4^{\mathrm{s}}$ & $42.1^{\star}$ & $42.7^{b}$ & .84 \\
\hline With urea & $49.6^{5}$ & $59.5^{\circ}$ & $43.1^{b}$ & .84 \\
\hline \multicolumn{5}{|c|}{ Neutral detergent fiber } \\
\hline Without urea & $49.5^{*}$ & $50.1^{2}$ & $60.7^{\circ}$ & .83 \\
\hline With urea & $62.3^{3}$ & 69.9 & $61.6^{\circ}$ & .83 \\
\hline
\end{tabular}

'Grass species $\mathrm{x}$ urea supplementation interaction $(P<0.05)$

at $\times$ Vilues within item lacking a common superscript letter differ $(P<0.05)$.

ses, effects of buffer additions on dry matter and neutral detergent fiber disappearances and rate kinetics were analyzed separately for each range grass type by least squares procedures using GLM of SAS with supplement and run as independent variables. Treatment effects were tested using supplement $\mathrm{x}$ run as the error term. When a significant $F$ value was indicated, supplement mean separation was accomplished by the Waller-Duncan test (SAS 1985).

\section{Results and Discussion}

Interactions occurred $(P<0.05)$ between the effect of urea addition to the buffer and grass species for in vitro dry matter disappearance and in vitro neutral detergent fiber disappearance. The shortgrasses had higher $(P<0.05)$ in vitro dry matter disappearance and in vitro neutral detergent fiber disappearance than westem wheatgrass when no urea was added to the buffer (Table 3 ). Urea addition increased $(P<0.05)$ in vitro dry matter disappearance of western wheatgrass and Japanese brome 10.2 and 17.4 percentage units over their respective counterparts with $\mathbf{N}$ free buffer. Values for in vitro neutral detergent fiber disappearance reflected those increases in in vitro dry matter disappearance when urea was added. Japanese brome had higher $(P<0.05)$ in vitro dry matter disappearance and in vitro neutral detergent fiber disappearance than either western wheatgrass or shortgrasses when urea was added. Urea buffer addition did not improve shortgrass in vitro dry matter disappearance or in vitro neutral detergent fiber disappearance over buffer alone.

Composition differences between the cool and warm season grasses may explain the differing effects of urea addition on grass digestibility. The shortgrasses had higher crude protein content and lower fiber levels than either of the cool season grasses. Stern et al. (1978) suggested that carbohydrate availability was a major factor affecting $\mathrm{NH}_{3}-\mathrm{N}$ utilization by rumen microbes. Assuming that a portion of the neutral detergent fiber content is available for cellulolytic digestion, then the ratio of crude protein to available carbohydrate would be higher and $\mathrm{NH}_{3}$ would be less limiting for shortgrasses than for the warm season grasses. Lignin and ash content were higher in shortgrasses. The ash content, primarily silica, and lignin may have an additive effect in blocking further cell was digestion (Van Soest and Jones 1968) and limiting extent of final digestion (Mertens 1977) of the warm season grasses.

Cumulative gas production curves for incubations containing added urea were similar to typical cumulative cell wall digestion curves reported by Mertens (1977). Gas production was linear for incubations containing grass samples without urea addition and resulted in lower 48-hour total gas production. Gas production of nearly 0 was recorded for incubations containing buffers and rumen fluid without forage. In general, fermentation lag times were shorter than dry matter and neutral detergent fiber disappearance lag times determined by Clark and Petersen (1985). The mathematical model used to determine lag periods may influence calculated lag phases (Nocek and English 1986). Nonlinear iterative least squares regression tends to underestimate lag phase compared to logarithmic transformations when degradation of a single fraction (e.g., neutral detergent fiber) of the substrate is concerned (Mertens and Loften 1980; Nocek and English 1986). In vitro cumulative gas production incorporates disappearance of both soluble fractions and the less degradable components of the substrate and may result in shorter predicted lag phases.

In vitro dry matter disappearance of western wheatgrass was not increased by buffer additions over urea alone and was decreased $(P<0.05)$ by arginine (Table 4$)$. Methionine addition increased $(P<0.05)$ in vitro detergent fiber disappearance of western wheatgrass over urea alone. Lag time and time to maximum fermentation for western wheatgrass were not changed over urea alone with the addition of amino acids, branched-chain volatile fatty acids, or $\mathrm{Na}_{2} \mathrm{SO}_{4}$. Starch addition did reduce lag time and time to maximum fermentation. Fermentation rate of western wheatgrass was increased $(P<0.05)$ by methionine or starch and was decreased $(P<0.05)$ by arginine compared to urea alone. Since starch addition did not affect in vitro dry matter disappearance or in vitro neutral detergent fiber disappearance, changes in rate and time of maximum fermentation are probably due only to starch fermentation.

Methionine increased $(P<0.05)$ in vitro dry matter disappearance, and $\mathrm{Na}_{2} \mathrm{SO}_{4}$ or methionine increase $(P<0.05)$ in vitro neutral detergent fiber disappearance of Japanese brome over urea alone (Table 5). Histidine or leucine decreased $(P<0.05)$ in vitro dry matter disappearance and leucine decreased $(P<0.05)$ in vitro neutral detergent fiber disappearance of Japanese brome over

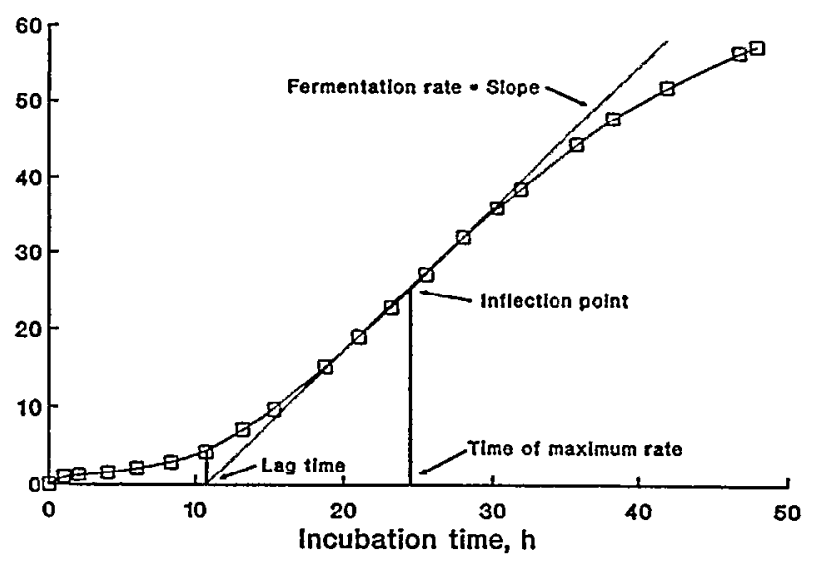

Fig. 2. Cumulative water displacement during 48 hour in vitro fermentation of WWG with methionine addition to the buffer solution. The slope of the iterative least squares regression line is equal to the rate of gas production during the growth phase. The value of $x$ at the inflection point reflects time of maximum fermentation rate. The point at which the $x$ axis is intersected by the least squares regression line is equal to duration of the lag phase. 
Table 4. Effects of in vitro buffer supplements on digestibility of western wheatgrass

\begin{tabular}{|c|c|c|c|c|c|}
\hline Addition & $\begin{array}{c}\text { Dry } \\
\text { matter } \\
\text { disappear- } \\
\text { ance }\end{array}$ & $\begin{array}{c}\text { Neutral } \\
\text { detergent } \\
\text { fiber } \\
\text { diasppear- } \\
\text { ance }\end{array}$ & $\begin{array}{l}\text { Lag } \\
\text { time }\end{array}$ & $\begin{array}{l}\text { Fermenta- } \\
\text { tion } \\
\text { ratc }\end{array}$ & $\begin{array}{l}\text { Time of } \\
\text { maximum } \\
\text { rate }\end{array}$ \\
\hline & $(C)$ & $(\%)$ & \multicolumn{3}{|c|}{ (hour) (ml Hº/ hour) (hour) } \\
\hline Urea & $49.0^{3}$ & $60.4^{2}$ & $16.9^{2}$ & $1.70^{x=}$ & $30.6^{\circ}$ \\
\hline \multicolumn{6}{|l|}{ Amino acids } \\
\hline Arginine & $45.5^{\star}$ & $62.9^{\star}$ & $16.6^{\circ}$ & $1.54^{\operatorname{sef}}$ & $31.2^{2}$ \\
\hline Histidine & $48.0^{-5}$ & $61.8^{2 x}$ & $14.9 * *$ & $1.88^{20}$ & $28.9^{-x}$ \\
\hline Isoleucine & $48.6^{\circ}$ & $61.6^{2 \times}$ & $15.3^{2 \times x}$ & $1.77^{2 \times 2 \times}$ & $28.7^{\star}$ \\
\hline Leucine & $47.9^{3}$ & $63.2^{\mathrm{te}}$ & $16.2^{2}$ & $1.77^{2 \times \mathrm{d}}$ & $30.1^{2 x}$ \\
\hline Methionine & $49.8^{3}$ & $64.6^{\circ}$ & $15.3^{2 x}$ & $1.92^{3}$ & $29.8^{\mathrm{si}}$ \\
\hline \multicolumn{6}{|c|}{ Branched-chain volatile fatty acids } \\
\hline Isobutyric acid & $49.4^{2}$ & $61.2^{ \pm 2}$ & $16.6^{*}$ & $1.68^{5 *}$ & $29.8^{20}$ \\
\hline Isovaleric acid & $47.1^{2}$ & $62.7^{\infty}$ & $15.9^{m \times}$ & $1.43^{t}$ & $29.3^{2 i}$ \\
\hline 2-methylbutyric acid & $48.3^{\mathrm{s}}$ & $62.7^{*}$ & $15.9^{\circ \mathrm{n}}$ & $1.43^{x}$ & $29.3^{25}$ \\
\hline $\mathrm{Na}_{2} \mathrm{SO}_{4}$ & $48.6^{\circ}$ & $60.5^{\circ}$ & $16.6^{\circ}$ & $1.50^{=s}$ & $30.4^{2 x}$ \\
\hline Starch & $47.6^{\circ}$ & 62.8 & $13.4^{\circ}$ & $1.94^{\circ}$ & $28.1^{\circ}$ \\
\hline $\operatorname{SEM}(n-2)$ & 1.1 & 1.2 & 0.67 & 0.077 & 0.74 \\
\hline
\end{tabular}

er. se Values within a column lacking a comon supersenpt letter differ $(P<0.05)$.

urea addition. Fermentation lag time for Japanese brome was decreased $(P<0.05)$ by histidine, isoleucine, or starch. Time to maximum fermentation rate was decreased $(P<0.05)$ by histidine, isoleucine, methionine, 2-methylbutyric acid, or starch compared to urea. Isoleucine, methionine, or starch increased fermentation rate of Japanese brome over urea.

Amino acid, branched-chain volatile fatty acid, $\mathrm{Na}_{2} \mathrm{SO}_{4}$, or starch additions did not affect in vitro dry matter disappearance or in vitro neutral detergent fiber disappearance of shortgrasses over urea (Table 6). methionine increased $(P<0.05)$ shortgrass lag time. Arginine, leucine, or methionine increased $(P<0.05)$ and starch decreased $(P<0.05)$ time to maximum fermentation rate of shortgrasses. Fermentation rate of shortgrasses was increased $(P<0.05)$ by histidine and starch over urea alone.

Fermentation rates and neutral detergent fiber disappearance of cool season grasses were increased with the addition methionine, These results were not observed with shortgrasses. As suggested previously, there appears to be very distinct digestible fiber and indigestible fiber/lignin/ash fractions in the shortgrasses. The higher lignin and silica content of shortgrasses has been associated with slower in vitro fermentation rates and extent of fiber digestibility (Smith et al. 1971; Van Soest and Jones 1968). The smaller digestible fiber fraction in combination with the relatively higher crude protein content of shortgrasses may have been the reason that no responses to urea, amino acid, or branched-chain volatile fatty acid buffer additions were observed with the warm season grasses. Clark and Petersen (1985) found that in vitro dry matter and neutral detergent fiber fermentation rates of dormant range forage were increased by methionine but saw no improvement in 48-hour forage disappearance. Methionine supplementation of cattle consuming mature cool season grasses has been shown to increase neutral detergent fiber and dry matter disappearance rates (Lodman et al. 1990; Wiley et al. 1991).

The addition of $\mathrm{Na}_{2} \mathrm{SO}_{4}$ with urea did not elicit the fermentation responses which were observed with methionine in this study. Clark and Petersen (1988) reported an increase in dry matter fermentation rate for heifers fed methionine compared to
Table 5. Effects of in vitro buffer supplements on digestibility of Japanese brome

\begin{tabular}{|c|c|c|c|c|c|}
\hline Addition & $\begin{array}{c}\text { Dry } \\
\text { matter } \\
\text { disappear- } \\
\text { ance }\end{array}$ & $\begin{array}{c}\text { Neutral } \\
\text { detergent } \\
\text { fiber } \\
\text { diasppear- } \\
\text { ance }\end{array}$ & $\begin{array}{l}\text { Lag } \\
\text { time }\end{array}$ & $\begin{array}{l}\text { Fermenta- } \\
\text { tion } \\
\text { ratc }\end{array}$ & $\begin{array}{l}\text { Time of } \\
\text { maximum } \\
\text { rate }\end{array}$ \\
\hline & $(\%)$ & $(\%)$ & \multicolumn{3}{|c|}{ (hour) (ml H'0/ hour) (hour) } \\
\hline $\begin{array}{l}\text { Urea } \\
\text { Amino acids }\end{array}$ & $58.1^{\star s}$ & $68.8^{\circ}$ & $15.7^{3}$ & $1.81^{2}$ & $31.4^{2}$ \\
\hline Arginine & $56.4^{: \mathrm{d}}$ & $68.2=4$ & $13.5^{\mathrm{ax}}$ & $1.82^{4}$ & $31.0^{\circ}$ \\
\hline Histidine & $54.4^{46}$ & $67.2^{e x}$ & $12.1^{\circ}$ & $1.93^{\circ}$ & $29.3^{x=}$ \\
\hline Isoleucine & $59.0^{*}$ & $71.4 \mathrm{x}$ & $13.3^{\infty}$ & $2.05^{n}$ & $29.5^{\star}$ \\
\hline Leucine & $52.7^{\circ}$ & $65.6^{i}$ & $14.4^{2 \times-}$ & $1.71^{\star}$ & $32.1^{\circ}$ \\
\hline Methionine & $63.0^{3}$ & $74.0^{3}$ & $14.2^{-3 x}$ & $2.81^{\mathrm{s}}$ & $26.9^{1}$ \\
\hline \multicolumn{6}{|c|}{ Branched-chain volatile fatty acids } \\
\hline Isobutyric acid & $58.9^{\circ}$ & $69.8 b^{-5}$ & $15.7^{*}$ & $1 . \$ 4$ & $30.9^{2}=$ \\
\hline Isovaleric acid & $55.8 \div$ & $69.2^{2 * 5}$ & $13.5 \times$ & $1.81^{\circ}$ & $30.4 \div$ \\
\hline 2-methylbutyric acid & $57.2^{\mathrm{sad}}$ & $70.0 \cdots$ & $13.5^{2 \times}$ & $1.77^{\mathrm{s}}$ & $29.7^{*}$ \\
\hline $\mathrm{Na}_{2} \mathrm{SO}_{4}$ & $60.4^{2}$ & $72.55^{3}$ & $16.1^{\mathrm{s}}$ & $1.90^{43}$ & $30.6^{\text {as }}$ \\
\hline Starch & $57.5^{\star \mathrm{s}}$ & $70.6^{\circ \mathrm{st}}$ & $12.1^{\mathrm{c}}$ & $2.29=$ & $29.0^{*}$ \\
\hline $\operatorname{SEM}(\mathrm{n}-2)$ & 1.3 & 1.1 & 0.78 & 0.079 & 0.58 \\
\hline
\end{tabular}

abcae Values within a column lacking a comon superscript letter differ $(P<0.05)$.

ammonium sulfate but found no differences in dry matter ruminal digestibility. The degree to which methionine is used as an intact amino acid versus being degraded and used as a sulfur source by cellulolytic microbes in the rumen remains unclear. Numerous researchers (Hunt et al. 1954; Gil et al. 1973 Spears et al. 1976) have demonstrated that methionine when used as a sulfur source increases cellulose digestion. Maeng et al. (1976) suggested that sulfur amino acids were utilized intact and improved in vitro microbial cell yields with cellobiose as the substrate. Gawthorne and Nader (1976) determined that only $50 \%$ of the sulfur amino acid content of microbial protein was derived from the sulfite pool with the remainder from direct amino acid incorporation into the microbes. Salter et al. (1979) found that microbial incorpora-

Table 6. Effects of in vitro buffer supplements on digestibility of shortgrass mixture

\begin{tabular}{|c|c|c|c|c|c|}
\hline Addition & $\begin{array}{c}\text { Dry } \\
\text { matter } \\
\text { disappear- } \\
\text { ance }\end{array}$ & $\begin{array}{l}\text { Neutral } \\
\text { detergent } \\
\text { fiber } \\
\text { diasppear- } \\
\text { ance }\end{array}$ & $\begin{array}{l}\text { Lag } \\
\text { time }\end{array}$ & $\begin{array}{l}\text { ermenta- } \\
\text { tion } \\
\text { rate } \\
\end{array}$ & $\begin{array}{c}\text { Time of } \\
\text { maximum } \\
\text { rate }\end{array}$ \\
\hline & $(\%)$ & $(\%)$ & \multicolumn{3}{|c|}{ (hour) (ml H'0/ hour) (hour) } \\
\hline Urea & $43.8^{3}$ & $64.1^{2}$ & $9.3^{\Delta x}$ & $1.13^{2}$ & $22.4^{\circ}$ \\
\hline \multicolumn{6}{|l|}{ Amino acids } \\
\hline Arginine & $41.0^{*}$ & $63.6^{3}$ & $9.6^{2 \times}$ & $1.10^{3}$ & $25.3 \div$ \\
\hline Histidine & $43.6^{+3}$ & $63.9^{3}$ & $8.9^{\circ}$ & $1.41^{\text {th }}$ & $22.4^{*}$ \\
\hline Isoleucine & $44.0^{-}$ & $64.5^{\mathrm{a}}$ & $10.4^{2 \times d}$ & $1.22^{\Delta x}$ & $24.0^{5 \times 5}$ \\
\hline Leucine & $44.1^{\circ}$ & $65.2^{2}$ & $11.5^{\text {st }}$ & $1.33^{\mathrm{tad}}$ & $25.2^{35}$ \\
\hline Methionine & $42.8^{2 x}$ & $63.8^{2}$ & $12.3^{\mathrm{s}}$ & $1.32^{\mathrm{x}}$ & $26.5^{s}$ \\
\hline \multicolumn{6}{|c|}{ Branched-chain volatile fatty acids } \\
\hline Isobutyric acid & $43.3 * 0$ & $64.7^{\mathrm{a}}$ & $10.6^{0 \times 1}$ & $1.26^{2 x}$ & $23.1^{\star * *}$ \\
\hline Isovaleric acid & $42.9^{350}$ & $64.5^{3}$ & $10.2^{2 \times s c}$ & $1.16^{\circ}$ & $23.4^{2 x}$ \\
\hline 2-methylbutyric acid & $44.2^{\mathrm{a}}$ & $64.3^{3}$ & $9.2^{2 \times}$ & $1.11^{\mathrm{a}}$ & $22.3^{\star}$ \\
\hline $\mathrm{Na}_{2} \mathrm{SO}_{4}$ & $41.7^{3 x}$ & $62.6^{2}$ & $10.5^{2 \times d}$ & $1.05^{\star}$ & $22.5^{3}$ \\
\hline Starch & $42.7 \approx$ & $64.1^{2}$ & $7.9^{\mathrm{s}}$ & $1.53^{4}$ & $21.1^{2}$ \\
\hline $\operatorname{SEM}(n=2)$ & 1.1 & 1.0 & 0.82 & 0.072 & 0.83 \\
\hline
\end{tabular}

a.c.,.o Values within a column lacking a common superscript Ietter differ $(P<0.05)$ 
tion of methionine decreased when urea was the primary $\mathrm{N}$ source compared to a natural protein $\mathbf{N}$ source. While methionine is degraded more slowly than other amino acids in vivo, free amino acids exist in rumen fluid only in low concentrations (Scheifinger et al. 1976). In addition, during normal microbial turnover of a mixed rumen population, microbes that synthesize methionine from sulfite may provide methionine to microbes that utilize or degrade methionine. Scheifinger et al. (1976) determined that the group of cellulolytic bacteria Butyrivibrio cause a net degradation of methionine.

In vitro sulfur addition in combination with urea has long been known to increases microbial $\mathrm{NH}_{3}$ fixation (Hunt et al. 1954) and enhance cellulose digestion (Barton et al. 1971). Sulfate is reduced to sulfite in rumen fluid and incorporated into microbial protein as sulfur containing amino acids (Mathers and Miller 1980). While $\mathrm{Na}_{2} \mathrm{SO}_{4}$ did increase in vitro neutral detergent fiber disappearance of Japanese brome in this study, improvements in extent or rate of forage digestibility for sulfur additions over urea alone were not observed. In this trial, sulfur was provided at $28.56 \mathrm{mg} /$ deciliter buffer in order to be isosulfur to the methionine treatment. Kahlon et al. (1975) determined that $4.33 \mathrm{mg}$ S/deciliter inoculum were near optimum for microbial protein synthesis, while levels above $10.0 \mathrm{mg} \mathrm{S} /$ deciliter were inhibitory using a starch substrate. Although Fron et al. (1990) suggested that $\mathrm{Na}_{2} \mathrm{SO}_{4}$ had equal sulfur biological value as DL-methionine in cattle, Johnson et al. (1970) suggested that $\mathrm{Na}_{2} \mathrm{SO}_{4}$ was a more volatile sulfur source in the rumen than either methionine or elemental sulfur and would be less available for slowly degraded mature forages.

Branched-chain volatile fatty acids did not affect dry matter or fiber disappearance or improve fermentation kinetics of the dormant range grasses used in this study. Mir et al. (1986) found that these 3 branched-chain rolatile fatty acids, when added alone or in combination, increased in vitro dry matter disappearance of barley straw. In agreement with out results, these same branched-chain volatile fatty acids had no effect on rate or extent of in vitro dry matter disappearance or in vitro neutral detergent fiber disappearance of dormant range forages collected via esophageal fistula in a study reported by Clark and Petersen (1985). Similarly, McCollum et al. (1987) determined that 4- and 5-carbon volatile fatty acids were not limiting in vivo cellulolytic activity in the rumen of cattle fed mature low protein prairie hay.

In vitro screening of amino acid and branched-chain volatile fatty acid buffer supplements with dormant range grasses showed that methionine offered the greatest potenial for improving digestibility and rate of fermentation of mature cool season grasses. Response of supplements appears to be forage specific. From this study, it can not be determined whether these improvements were due to intact methionine or highly available sulfur from methionine. Neither urea nor any of the amendments tested improved fermentation of the warm season grasses.

\section{Conclusions}

These in vitro results indicate a relative ranking of individual amino acid or branched-chain volatile fatty acid additions with regard to their potential for improving utilization of urea supplements for ruminants consuming mature low protein forages. While responses observed with in vitro ruminal fermentations may not always occur in vivo, screening a number of treatments for their effect on a given ruminal response is useful in deriving in vivo treatments. In this study, methionine would appear to offer some benefit for improving utilization of urea based supplements to dormant cool season forage.

\section{Literature Cited}

Barton, J.S., L.S. Bull, and R.W. Hemken. 1971. Effects of various levels of sulfur upon cellulose digestion in purified diets and lignocellulose digestion in com fodder pellets. J. Anim. Sci. 33:682-685.

Clanton, D.C. 1978. Non-protein nitrogen in range supplements. J. Anim. Sci. 47:765-779.

Clark, C.K., and M.K. Peterson. 1985. Influence of amino acids or branched chain organic acids on in vitro fermentation of winter range forage. Proc. Western Section Amer. Soc. Anim. Sci. 36:310-313.

Clark, C.K., and M.K. Peterson. 1988. Influence of DL-methionine supplementation on growth, ruminal fermentation, and dilution rates in heifers. J. Anim. Sci. 66:743-749.

Dybing, C.D., P.D. Evenson, and C. Lay. 1988. Relationship among daily flower production, length of the flowering preiod and seed yeild of flax. Crop Sci. 28:287-292.

Fron, M.J., J.A. Boling, L.P. Bush, and K.A. Dawson. 1990. Sulfur and nitrogen metabolism in the bovine fed different forms of supplemental sulfur. J. Anim. Sci. 68:543-552.

Gawthorne, J.M. and C.J. Nader. 1976. The effect of molybdenum on the conversion of sulphate to sulphide and microbial-protein-sulphur in the rumen of sheep. Brit. J. Nutr. 35:11-23.

Gil, L.A., K.L. Shirley, and J.E. Moore. 1973. Effect of methionine hydroxy analog on bacterial protein systhesis from urea and glucose, starch of cellulose by numen micobes, in vitro. J. Anim. Sci. 37:159163.

Goering, H.K., and P.J. Van Soest. 1970. Forage fiber analysis (apparatus reagents, procedures, and some applications). Agr. Handb. 379. ARS, USDA, Washington, D.C.

Hunt, C.H., O.G. Bentley, T.V. Hershberger, and J.H. Cline, 1954. The effect of carbohydrates and sulfur on B-vitamin synthesis, cellulose digestion, and urea utilization by rumen microorganisms in vitro. J. Anim. Sci. 13:570-580.

Johnson, W.H., R.D. Goodrich, and J.C. Meiske. 1970. Appearance in the blood plasma and excretion of ${ }^{35} S$ from three chemical forms of sulfur by lambs. J. Anim. Sci. 31:1003-1009.

Kahlon, T.S., J. C. Meiske, and R.D. Goodrich. 1975. Sulfur metabolism in ruminants. I. In vitro availability of various chemcials forms of sulfur. J. Anim. Sci. 41:1147-1153.

Lodman, D.W., M.K. Petersen, C.K. Clark, J.S. Wiley, K.M. Havstad, and M.J. McInerney. 1990. Substitution of DL-methionine for soybean meal as a winter supplement for gestating cows grazing native range. J. Anim. Sci. 68:4361-4375.

Maeng, W.J., C.H. Van Nevel, R.L. Baldwin, and J.G. Morris. 1976. Rumen microbial growth rates and yields: Effects of amino acids and protein. J. Dairy Sci. 59:68-79.

Martin, G.C., and R.F. Barnes. 1980. Prediction of energy digestibility of forage with in vitro rumen fermentation and fungal enzyme systems, p. 61-71. In: C.C. Balch and M. Gramhan (Ed.) Standardization of analytical methodology for feeds. 1979. Proc. Int. Development Res. Center Ottawa, Canada.

Mathers, J.C., and E.L. Miller. 1980. A simple procedure using ${ }^{3 x}$ incorporation for the measurement of micorbial and undegraded food protein in ruminant digesta. Brit. J. Nutr. 43:503-514.

Mertens, D.R. 1977. Dietary fiber components: relationships to the rate and extent of ruminal digestion. Fed. Proc. 36:187-192.

Mertens, D.R., and J.R. Loften. 1980. The effect of strach on forage fiber digestion kinetics in vitro. J. Dairy Sci. 63:1437-1446.

McCollum, F.T., Y.K. Kim, and F.N. Owens. 1987. Influence of supplemental four- and five-carbon volatile fatty acids on forage intake and utilization by steers. J. Anim. Sci. 65:1674-1679. 
Mir, P.S., Z. Mir, and J.A. Robertson. 1986. Effect of branched-chain amino acids or fatty acid supplementation on in vitro digestibility of barley straw or alfalfa hay. Can. J. Anim. Sci. 66:151-156.

Nocek, J.E., and J.E. English. 1986. In situ degradation kinetics: evaluation of rate determination procedure. J. Dairy Sci. 69:77-87.

Rush, I.G., and R. Totusek. 1976. Supplemental value of feed grade biuret and urea-molasses for cows on dry winter grass. J. Anim. Sci. 42:497-505.

Salter, D.N., K. Daneshvar, and R.H. Smith. 1979. The origin of nitrogen incorporated into compounds in the rumen bacteria of steers given protein- and urea-containing diets. Brit. J. Nutr. 41:197-209.

SAS. 1981. SAS Views: Regression and ANOVA, p. 9.12-9.14. SAS Inst., Inc., Cary, N.C.

SAS. 1985. SAS User's Guide: Statistics (5th Ed.). SAS Inst., Inc., Cary, N.C.

Scheifinger, C., N.Russell, and W. Chalupa. 1976. Degradation of amino acids by pure cultures of rumen bacteria. J. Anim. Sci. 43:821827.

Sylter, L.L., W. Chapula, and R.R. Oltjen. 1988. Response to elemental sulfur by calves and sheep fed pruified diets. J. Anim. Sci. 66:10161027.

Smith, L.W., H.K. Goering, D.R. Waldo, and C.H. Gordon. 1971. In vitro digestion rate of forage cell wall components. J. Dairy Sci. 54:7176.
Soofi, R., G.C. Fahey, Jr., L.L. Berger, and F.C. Hinds. 1982. Effect of branched chain volatile fatty acids, trypticase, urea, and starch on in vitro dry matter disappearance of soybean stover. J. Dairy Sci. 65:1748-1753.

Spears, J.W., D.G. Ely, L.P. Bush, and R.C. Buckner. 1976. Sulfur supplementation and in vitro digestion of forage cellulose by rumen microorganisms. J. Anim. Sci. 43:513-517.

Stern, M.D., H. Hoover, C.J. Sniffen, B.A. Crooker, and P.H. Knowlton. 1978. Effects of nonstructural carbohydrate, urea, and soluble protein levels on microbial protein synthesis in continuous culture of rumen contents. J. Anim. Sci. 47:944-956.

Tilley, J.M., and R.A. Terry. 1963. A two-stage technique for the in vitro digestion of forage crops. J. Brit. Grassld. Soc. 10:104-111.

Van Soest, P.J., and L.H.P. Jones. 1968. Effect of silica in forages upon digestibility. J. Dairy Sci. 51:1644-1648.

Wiley, J.S., M.K. Petersen, C.K. Clark, R.P. Ansotegui, and D.W. Lodman. 1991. The influence of timing and the addition of urea to supplements containing DL-methionine on ruminal fermentation and cow weight change in beef cows. J. Anim. Sci. 69:4617-1627.

Williams, D.L., J.V. Whiteman, and A.D. Tillman. 1969. Urea utilization in protein supplements for cattle consuming poor quality roughages on the range. J. Anim. Sci. 28:807-812. 